Bangladesh J. Bot. 49(1): 13-19, 2020 (March)

\title{
ROOT-SHOOT CHARACTERISTICS, YIELD AND ECONOMICS OF MUNGBEAN (VIGNA RADIATA L.) UNDER VARIABLE RATES OF PHOSPHORUS AND NITROGEN
}

\author{
Abdul Hadi Omran, Anchal Dass", Ga Rajanna, Shiva Dhar, \\ ANIL K Choudhary, SL Meena ANd SS Rathore
}

\author{
Division of Agronomy, ICAR-Indian Agricultural Research Institute, \\ New Delhi-110 012, India
}

Keywords: Monetary efficiency, Mungbean, Nitrogen, Phosphorus, Production efficiency

\begin{abstract}
A field experiment was conducted to study the effect of nitrogen $(\mathrm{N})$ and phosphorus $(\mathrm{P})$ nutrition on growth, yield, economics, production efficiency (PE) and monetary efficiency (ME) of mungbean. Application of $55 \mathrm{~kg} \mathrm{~N} / \mathrm{ha}$ caused improvement in root- and shoot-dry weight, leaf area index and biological yield. However, $40 \mathrm{~kg} \mathrm{~N} / \mathrm{ha}$ recorded the highest pod length $(8.2 \mathrm{~cm})$, grains/plant $(284)$, grain yield $(2.1$ t/ha), harvest index (29.4\%), net returns (1,28,651 AFN/ha), benefit: cost ratio (2.6), PE ( $24 \mathrm{~kg} / \mathrm{ha} /$ day) and $\mathrm{ME}\left(1,429 \mathrm{AFN} / \mathrm{ha} /\right.$ day). Use of $60 \mathrm{~kg} \mathrm{P}_{2} \mathrm{O}_{5} /$ ha resulted in the highest pod length $(8.3 \mathrm{~cm})$, seeds/plant (285), grain yield (2.0 t/ha), harvest index (30.5\%), net returns (1,161,22.9 AFN/ha), benefit: cost ratio (2.4), $\mathrm{PE}(22.4 \mathrm{~kg} / \mathrm{ha} /$ day $)$ and ME (1,290 AFN/ha/day). The combination of $40 \mathrm{~kg} \mathrm{~N} / \mathrm{ha}$ and $60 \mathrm{~kg} \mathrm{P}_{2} \mathrm{O}_{5}$ /ha recorded the highest yield, net returns, benefit: cost ratio, $\mathrm{PE}$ and $\mathrm{ME}$. Hence, mungbean grown field should be treated with $40 \mathrm{~kg} \mathrm{~N} / \mathrm{ha}$ and $60 \mathrm{~kg} \mathrm{P}_{2} \mathrm{O}_{5} /$ ha fertilizers for its higher productivity and profitability.
\end{abstract}

\section{Introduction}

In Afghanistan, pulses constitute the main source of protein, particularly for the poor masses, and domestic animals. The stem and leaves of pulses are used in preparing a concentrate feed for animals called Bhushi, and mungbean seeds are mostly used as an excellent source of vegetable protein in Afghanistan. It is used as whole or split seed as Dal (soup) in home and as fried Dal in Kandahar region of Afghanistan (Omran et al. 2018). The mungbean also plays an important role in sustaining soil fertility by improving soil $\mathrm{N}$ status by fixing atmospheric nitrogen, which makes it an excellent source of green-manure. Mungbean being a deep rooted crop absorbs nutrients from the sub-soil, as a result enriching the plough layers (Prasad and Kerkerra 1991). All these benefits make mungbean as an inevitable component of sustainable agriculture. Mungbean has a special importance in intensive crop production system since it requires short growing period. Summer mungbean tolerates a high temperature up to $40^{\circ} \mathrm{C}$. It is reported to be drought tolerant and can be cultivated in an area of low rainfall. Thus, mungbean is sown in warm region of the country like Kunduz, Helmand, Kandahar, Nangarhar, Parwan, Baghlan, Laghman, Takhar, Kapisa, etc (USAID 2007). The average yield of mungbean in Afghanistan varies with level of agronomic management. However, small and marginal farmers do not apply balanced fertilizers in mungbean that results in poor yield. As imbalanced application of chemical fertilizers is also detrimental to the environment, there is an exigency in Afghanistan to increase the mungbean yield through proper $\mathrm{N}$ and $\mathrm{P}$ fertilization as these two major plant nutrients determine several metabolic and physiological processes in plant and thereby, influence growth, yield and quality of crop. Addition both of these nutrients to soil shows synergistic effect on plant. In pulses, supply of $\mathrm{P}$ is particularly important for its numerous roles in plant growth and production (Dass et al. 1997,

*Author for correspondence: <anchal_iari@rediffmail.com>. 
Dass et al. 2005). Hence, the present field experiment was conducted to study the effect of $\mathrm{N}$ and $\mathrm{P}$ nutrition on the growth, yield and economics of mungbean.

\section{Materials and Methods}

The field experiment was conducted at the Experimental Farm of Afghanistan National Agricultural Science and Technology University (ANASTU), Kandahar, Afghanistan, during May - August, 2015 in a sandy clay loam soil. The important properties of soil are shown in Table 1. The Kandahar province is located in the southern part of the country having tropical to subtropical climate with slightly semi-arid, hot and dry summers, moderate rainfall and little cold winter. December, January and February are usually the coldest months where the mean temperature normally falls as low as $5.1^{\circ} \mathrm{C}$ (January); whereas, June to August are the hottest months, having maximum average temperature of $31.9^{\circ} \mathrm{C}$ (July). The seasonal rainfall of 190.6 $\mathrm{mm}$ is received mostly from December to March in winter season. The details of meteorological observations recorded as weekly maximum and minimum temperature, rainfall, relative humidity and rainy days from May, 2015 to August, 2015 were collected from agro-meteorological observatory, Kandahar University, Kandahar.

Table 1. Properties of experimental field soil.

\begin{tabular}{ll}
\hline Particulars & Value \\
\hline Sand & $44.1 \%$ \\
Silt & $10.3 \%$ \\
Clay & $45.6 \%$ \\
Texture & Sandy-clay loam \\
Water holding capacity $(\%)$ & $35 \%$ \\
pH value & 8.30 \\
Conductivity (Milimhos/cm) & 0.21 \\
Organic carbon $(\%)$ & 0.10 \\
Available nitrogen $(\% \mathrm{w} / \mathrm{w})$ & 0.06 \\
\hline
\end{tabular}

The experiment was conducted using a factorial randomized block design (RBD) with three replications. The treatments comprised three $\mathrm{N}$ levels $(25,40$ and $55 \mathrm{~kg} \mathrm{~N} / \mathrm{ha})$, three P levels (40, 60 and $\left.80 \mathrm{~kg} \mathrm{P}_{2} \mathrm{O}_{5} / \mathrm{ha}\right)$ and one absolute control $\left(\mathrm{N}_{0} \mathrm{P}_{0}\right)$. Each experimental unit was of $3 \mathrm{~m} \times 4 \mathrm{~m}$ size. Well decomposed farm yard manure (FYM) was applied @ $10 \mathrm{t} / \mathrm{ha}$ and incorporated into the soil, 10 days before sowing. Potassium was uniformly applied at the rate of $30 \mathrm{~kg} / \mathrm{ha}$. Nitrogen was applied through urea and P through (TSP) at the rates as shown in the treatments. The mungbean variety Mash 2008 was sown at a spacing of $30 \times 10 \mathrm{~cm}$ using $30 \mathrm{~kg} / \mathrm{ha}$ seed. All recommended cultural practices were followed and the crop was harvested at maturity. Plants were selected randomly from each plot for recording shoot dry weight/ plant, root dry weight/plant, leaf area index (LAI), pod length $(\mathrm{cm})$ and number of seeds/plant. Seed yield and biological yield were computed by harvesting and threshing crop from net-plots separately. Cost of cultivation, gross return, net return were computed by taking into account the prevailing market prices for all in-puts and economic products of crop. Production efficiency (PE) was calculated by dividing seed yield with crop duration, and monetary efficiency (ME) by dividing net returns with crop duration. The data were analyzed by using (ANOVA technique) for factorial RBD as per the procedures given 
by Gomez and Gomez (1984). The significance of difference among different treatments was tested using F-test. Critical difference (LSD) values were calculated for the parameters that exhibited significant differences. The treatment means were compared at $5 \%$ level of significance.

\section{Results and Discussion}

Application of $\mathrm{N}$ and $\mathrm{P}$ significantly improved all studied growth parameters of mungbean, over control $\left(\mathrm{N}_{0} \mathrm{P}_{0}\right)$. Within $\mathrm{N}$ rates, the maximum, dry root weight/plant, shoot dry weight/plant, shoot : root ratio and LAI were recorded with $55 \mathrm{~kg} \mathrm{~N} / \mathrm{ha}$, but the difference between 40 and $55 \mathrm{~kg}$ N/ha was non-significant for root dry weight. Quah and Jaafar (1994) and Mian and Hossain (2014) also reported that application of $\mathrm{N} @ 60 \mathrm{~kg} / \mathrm{ha}$ significantly improved growth parameters of mungbean. Among P rates, the application of $\mathrm{P}_{2} \mathrm{O}_{5} @ 80 \mathrm{~kg} / \mathrm{ha}$ caused significantly higher dry root weight/plant, shoot dry weight/plant and LAI than 60 and $40 \mathrm{~kg} \mathrm{P}_{2} \mathrm{O}_{5}$; the difference between 40 and $60 \mathrm{~kg} \mathrm{P}_{2} \mathrm{O}_{5}$ was not significant (Table 2). Phosphorus promotes the $\mathrm{N}$ availability for its efficient utilization by the plants, which helps boosting the plant growth. Ullah et al. (2010) reported plant response in mungbean up to $90 \mathrm{~kg}_{2} \mathrm{O}_{5} / \mathrm{ha}$. Mian and Hossain (2014), Prasad et al. (2014) also reported that application of $75 \mathrm{~kg} \mathrm{P}_{2} \mathrm{O}_{5}$ /ha significantly increased the dry root weight, shoot dry weight and total dry matter accumulation in mungbean (Table 2). Shoot : root ratio was also highest with $80 \mathrm{~kg} \mathrm{P}_{2} \mathrm{O}_{5} / \mathrm{ha}$.

Table 2. Effect of nitrogen and phosphorus rates on root- and shoot-characteristics, yields and harvest index of growth in mungbean.

\begin{tabular}{|c|c|c|c|c|c|c|c|c|c|}
\hline \multirow[t]{2}{*}{ Treatments } & \multicolumn{2}{|c|}{$\begin{array}{c}\text { Dry weight } \\
\text { (g/plant) }\end{array}$} & \multirow{2}{*}{$\begin{array}{c}\text { Shoot: } \\
\text { root } \\
\text { ratio }\end{array}$} & \multirow{2}{*}{$\begin{array}{l}\text { Leaf } \\
\text { area } \\
\text { index }\end{array}$} & \multirow{2}{*}{$\begin{array}{l}\text { Pod } \\
\text { length } \\
(\mathrm{cm})\end{array}$} & \multirow[t]{2}{*}{$\begin{array}{c}\text { Seeds/ } \\
\text { plant }\end{array}$} & \multicolumn{2}{|c|}{$\begin{array}{l}\text { Yield } \\
(\mathrm{t} / \mathrm{ha})\end{array}$} & \multirow{2}{*}{$\begin{array}{c}\text { Harvest } \\
\text { index } \\
(\%)\end{array}$} \\
\hline & Root & Shoot & & & & & Grain & Biological & \\
\hline \multicolumn{10}{|l|}{ Nitrogen } \\
\hline $\mathrm{N}_{1}$ & 2.8 & 41.8 & 6.70 & 4.3 & 7.3 & 279.3 & 1.84 & 6.16 & 29.2 \\
\hline $\mathrm{N}_{2}$ & 3.0 & 41.5 & 7.23 & 4.6 & 8.2 & 283.6 & 2.16 & 6.64 & 29.4 \\
\hline $\mathrm{N}_{3}$ & 3.4 & 45.4 & 7.36 & 5.2 & 7.3 & 256.0 & 1.82 & 6.94 & 27.4 \\
\hline $\operatorname{LSD}(0.05)$ & 0.35 & 3.30 & - & 0.47 & 0.53 & 23.35 & 0.152 & 0.484 & 1.96 \\
\hline \multicolumn{10}{|l|}{ Phosphorus } \\
\hline $\mathrm{P}_{1}$ & 2.9 & 41.0 & 7.07 & 4.3 & 7.2 & 264.2 & 1.79 & 6.23 & 28.1 \\
\hline $\mathrm{P}_{2}$ & 3.0 & 42.2 & 7.00 & 4.5 & 8.3 & 284.7 & 2.00 & 6.68 & 30.5 \\
\hline $\mathrm{P}_{3}$ & 3.4 & 45.6 & 7.46 & 5.1 & 7.4 & 263.9 & 2.10 & 6.73 & 28.0 \\
\hline LSD (0.05) & 0.35 & 3.30 & - & 0.47 & 0.53 & NS & 0.152 & 0.484 & 1.96 \\
\hline \multicolumn{10}{|l|}{ Control } \\
\hline Control & 2.03 & 36.0 & 5.64 & 3.5 & 5.5 & 160.6 & 1.13 & 4.46 & 22.0 \\
\hline Nutrients & 3.13 & 44.9 & 6.97 & 4.7 & 7.6 & 273.0 & 1.94 & 6.58 & 28.9 \\
\hline $\operatorname{LSD}(0.05)$ & 0.650 & 6.03 & - & 0.86 & 0.97 & 42.64 & 0.278 & 0.884 & 3.58 \\
\hline
\end{tabular}

The significant $\mathrm{N} \times \mathrm{P}$ interaction effects revealed that the maximum dry root weight, shoot dry weight and LAI were recorded with the combination of $55 \mathrm{~kg} \mathrm{~N} / \mathrm{ha}$ and $80 \mathrm{~kg} \mathrm{P}_{2} \mathrm{O}_{5}$ /ha, which was significantly higher than all other treatment combinations (Table 3). Both of these major nutrients are involved in plant metabolic processes that, in turn, improve the crop growth. 
Table 3. Interaction effects of nitrogen and phosphorus application rates on root dry K-weight, shoot dry and leaf area index of mungbean.

\begin{tabular}{|c|c|c|c|c|c|c|c|c|c|}
\hline \multirow[t]{2}{*}{$\begin{array}{l}\text { N \& P } \\
\text { levels }\end{array}$} & \multicolumn{3}{|c|}{$\begin{array}{l}\text { Root dry weight } \\
\text { (g/plant })\end{array}$} & \multicolumn{3}{|c|}{$\begin{array}{c}\text { Shoot dry weight } \\
\text { (g/plant) }\end{array}$} & \multicolumn{3}{|c|}{$\begin{array}{l}\text { Leaf area } \\
\text { index }\end{array}$} \\
\hline & $\mathrm{N}_{1}$ & $\mathrm{~N}_{2}$ & $\mathrm{~N}_{3}$ & $\mathrm{~N}_{1}$ & $\mathrm{~N}_{2}$ & $\mathrm{~N}_{3}$ & $\mathrm{~N}_{1}$ & $\mathrm{~N}_{2}$ & $\mathrm{~N}_{3}$ \\
\hline $\mathrm{P}_{1}$ & 2.2 & 2.3 & 2.6 & 40.7 & 41.1 & 41.3 & 3.9 & 4.5 & 4.6 \\
\hline $\mathrm{P}_{2}$ & 2.5 & 2.9 & 3.9 & 43.6 & 41.3 & 41.7 & 4.3 & 4.5 & 4.6 \\
\hline $\mathrm{P}_{3}$ & 3.9 & 3.0 & 4.4 & 41.3 & 42.3 & 50.3 & 4.6 & 4.8 & 6.1 \\
\hline $\operatorname{LSD}(0.05)$ & \multicolumn{3}{|c|}{0.617} & \multicolumn{3}{|c|}{5.72} & \multicolumn{3}{|c|}{0.82} \\
\hline
\end{tabular}

Like growth characteristics, yield attributes, seed yield, biological yield and harvest index significantly were increased by $\mathrm{N}$ and $\mathrm{P}$ fertilization compared to control. The longest pods bearing the highest number of seeds were observed in crop fertilized with $40 \mathrm{~kg} / \mathrm{ha}$ compared to the crop receiving 25 and $55 \mathrm{~N} / \mathrm{ha}$ (Table 2). The results are similar to the findings of Zabir (2015) who showed that application of $45 \mathrm{~kg} \mathrm{~N} / \mathrm{ha}$ produced longest pods and maximum number of seeds per plant. Likewise, $60 \mathrm{~kg} \mathrm{P}_{2} \mathrm{O}_{5} /$ ha resulted in highest number of seeds per plant, which was at par with other two P levels. But, further increase in P dose to $80 \mathrm{~kg} \mathrm{P}_{2} \mathrm{O}_{5} /$ ha did not increase yield attributes markedly. It is well established that $\mathrm{P}$ plays an important role in seed formation and the results of this investigation are just the reflection of the role of $\mathrm{P}$ in legumes like mungbean.

The $\mathrm{N} \times \mathrm{P}$ interaction had significant influence on number of seeds/plant. The maximum number of seeds/plant was observed with the combination of $40 \mathrm{~kg} \mathrm{~N} / \mathrm{ha}$ and $60 \mathrm{~kg} \mathrm{P}_{2} \mathrm{O}_{5} / \mathrm{ha}$ over other combinations (Table 3). The higher number of seeds might be due to acceleration of various enzymatic activities which controlled flowering, pod- and seed-formation (Dass et al. 1997).

Seed yield significantly was increased by $\mathrm{N}$ and $\mathrm{P}$ application rates, over control. Among $\mathrm{N}$ rates, application of $40 \mathrm{~kg} \mathrm{~N} / \mathrm{ha}$ increased seed yield by $17.4 \%$ over $25 \mathrm{~kg} \mathrm{~N} / \mathrm{ha}$ and by $18.7 \%$ over $55 \mathrm{~kg} \mathrm{~N} / \mathrm{ha}$ (Table 2). Further increase in N levels beyond $40 \mathrm{~kg} \mathrm{~N} / \mathrm{ha}$ caused negative influence on seed yield. Further, the highest biological yield was recorded with $55 \mathrm{~kg} \mathrm{~N} / \mathrm{ha}$ over $25 \mathrm{~kg} \mathrm{~N} / \mathrm{ha}$ but was at par with $40 \mathrm{~kg} \mathrm{~N} / \mathrm{ha}$ due to the fact that excess $\mathrm{N}$ promotes vigorous vegetative growth that supplemented in higher biological yield of mungbean. Similarly, application of $60 \mathrm{~kg} \mathrm{P}_{2} \mathrm{O}_{5} / \mathrm{ha}$ increased mungbean seed yield by 17.3 and $11.7 \%$ over $40 \mathrm{~kg} \mathrm{P}_{2} \mathrm{O}_{5} / \mathrm{ha}, 80 \mathrm{~kg} \mathrm{P}_{2} \mathrm{O}_{5} / \mathrm{ha}$, respectively. Mian and Hossain (2014) also reported that the application of $\mathrm{N}$ at the rate of 40 $\mathrm{kg} / \mathrm{ha}$ significantly increased seed yield of mungbean. Mungbean yield declined when $\mathrm{P}$ application was increased to $80 \mathrm{~kg} \mathrm{P}_{2} \mathrm{O}_{5} / \mathrm{ha}$. This depressing effect of the highest $\mathrm{P}$ level on yield of mungbean could likely be due to antagonistic interaction between $\mathrm{P}$ and micronutrients (B, Cu, Fe, Mn, Mo and $\mathrm{Zn}$ ). Overall, seed yield from $\mathrm{N}$ and $\mathrm{P}$ fertilizer applied plots was $71.6 \%$ higher over control plots. However, the maximum biological yield was recorded when P was applied @ $80 \mathrm{~kg} \mathrm{P}_{2} \mathrm{O}_{5} / \mathrm{ha}$, which was significantly higher than the treatment of $40 \mathrm{~kg}$ $\mathrm{P}_{2} \mathrm{O}_{5} /$ ha, but it was statistically at par with treatment $60 \mathrm{~kg} \mathrm{P}_{2} \mathrm{O}_{5} /$ ha. The outcomes of the present study confirm the finding of Khan et al. (2003) who observed that the maximum total biomass of mungbean was recorded by the application of $90 \mathrm{~kg} \mathrm{P}_{2} \mathrm{O}_{5} / \mathrm{ha}$. The highest harvest index of mungbean observed by the application $40 \mathrm{~kg} \mathrm{~N} / \mathrm{ha}$. P levels also significantly influenced the harvest index. The significantly higher harvest index was recorded using $60 \mathrm{~kg}_{2} \mathrm{O}_{5} /$ ha than other P levels (Prasad et al. 2014). 
Table 4. Interaction effect of nitrogen and phosphorus application rates on number of seeds, grain yield, biological yield and harvest index of mungbean.

\begin{tabular}{|c|c|c|c|c|c|c|}
\hline \multirow{2}{*}{$\begin{array}{l}\mathrm{N} \& \mathrm{P} \\
\text { levels }\end{array}$} & \multicolumn{3}{|c|}{ Seeds/plant } & \multicolumn{3}{|c|}{ Grain yield (t/ha) } \\
\hline & $\mathrm{N}_{1}$ & $\mathrm{~N}_{2}$ & $\mathrm{~N}_{3}$ & $\mathrm{~N}_{1}$ & $\mathrm{~N}_{2}$ & $\mathrm{~N}_{3}$ \\
\hline $\mathrm{P}_{1}$ & 240.3 & 272.7 & 236.6 & 1.6 & 2.0 & 1.7 \\
\hline $\mathrm{P}_{2}$ & 278.0 & 290.2 & 247.1 & 1.9 & 2.3 & 1.7 \\
\hline $\mathrm{P}_{3}$ & 279.6 & 227.9 & 224.3 & 1.9 & 2.0 & 2.0 \\
\hline \multirow[t]{2}{*}{$\operatorname{LSD}(0.05)$} & 40.45 & & & 0.26 & & \\
\hline & \multicolumn{3}{|c|}{ Biological yield (t/ha) } & \multicolumn{3}{|c|}{ Harvest index $(\%)$} \\
\hline $\mathrm{P}_{1}$ & 5.6 & 6.6 & 6.4 & 29.0 & 29.7 & 25.6 \\
\hline $\mathrm{P}_{2}$ & 6.1 & 6.3 & 6.5 & 31.4 & 31.2 & 28.8 \\
\hline $\mathrm{P}_{3}$ & 6.8 & 7.0 & 7.9 & 29.0 & 27.3 & 27.6 \\
\hline $\operatorname{LSD}(0.05)$ & 0.83 & & & 3.39 & & \\
\hline
\end{tabular}

Table 5. Effect of nitrogen and phosphorus application rate on gross returns, net returns to $\mathrm{B}$ : $\mathrm{C}$ ratio of mungbean.

\begin{tabular}{|c|c|c|c|c|c|c|}
\hline Treatments & $\begin{array}{l}\text { Cost of } \\
\text { cultivation } \\
\left(\mathrm{AFN}^{*} / \mathrm{ha}\right)\end{array}$ & $\begin{array}{c}\text { Gross } \\
\text { return } \\
\text { (AFN/ha) }\end{array}$ & $\begin{array}{l}\text { Net return } \\
\text { (AFN/ha) }\end{array}$ & $\begin{array}{l}\mathrm{B}: \mathrm{C} \\
\text { ratio }\end{array}$ & $\begin{array}{l}\text { Production } \\
\text { efficiency } \\
\text { (kg/ha/day) }\end{array}$ & $\begin{array}{c}\text { Monetary } \\
\text { equivalent } \\
\text { (AFN/ha/day) }\end{array}$ \\
\hline \multicolumn{7}{|l|}{ Nitrogen } \\
\hline $\mathrm{N}_{1}$ & 48,778 & $1,50,955$ & $1,02,177$ & 2.1 & 20.5 & 1135 \\
\hline $\mathrm{N}_{2}$ & 49,482 & $1,78,133$ & $1,28,651$ & 2.6 & 24.0 & 1429 \\
\hline $\mathrm{N}_{3}$ & 50,208 & $1,51,477$ & $1,01,269$ & 2.0 & 20.2 & 1125 \\
\hline LSD (0.05) & - & $10,665.8$ & $10,665.8$ & 0.22 & 1.69 & 118.5 \\
\hline \multicolumn{7}{|l|}{ Phosphorus } \\
\hline $\mathrm{P}_{1}$ & 48,179 & $1,48,711$ & $1,00,531$ & 2.1 & 20.0 & 1117 \\
\hline $\mathrm{P}_{2}$ & 49,499 & $1,65,622$ & $1,16,122$ & 2.4 & 22.5 & 1290 \\
\hline $\mathrm{P}_{3}$ & 50,789 & $1,65,233$ & $1,15,444$ & 2.3 & 21.3 & 1272 \\
\hline LSD (0.05) & - & $10,665.89$ & $10,665.89$ & 0.22 & 1.69 & 118.5 \\
\hline \multicolumn{7}{|c|}{ Control vs Rest } \\
\hline Control & 43,700 & 97,833 & 54,133 & 1.2 & 12.6 & 601.48 \\
\hline Nutrients & 49,489 & $1,60,188$ & $1,10,699$ & 2.2 & 21.6 & 1230 \\
\hline $\operatorname{LSD}(0.05)$ & - & $19,473.16$ & $19,473.16$ & 0.40 & 3.09 & 216.4 \\
\hline
\end{tabular}

*One AFN = 1.07 INR.

Among interaction effect of $\mathrm{N} \times \mathrm{P}$, the highest seed yield of mungbean was observed when 40 $\mathrm{kg} \mathrm{N} / \mathrm{ha}$ was applied with $60 \mathrm{~kg} \mathrm{P}_{2} \mathrm{O}_{5} /$ ha than other combinations. Conversely, the maximum biological yield of mungbean was found when $\mathrm{N}$ was applied @ $55 \mathrm{~kg} / \mathrm{ha}$ along with $80 \mathrm{~kg}$ $\mathrm{P}_{2} \mathrm{O}_{5}$ /ha which was significantly higher than all other treatment combinations. Karle and Pawar (1998) also reported that $\mathrm{N} @ 50 \mathrm{~kg} / \mathrm{ha}$ along with $50 \mathrm{~kg} \mathrm{P}_{2} \mathrm{O}_{5} /$ ha increased mungbean yield. $\mathrm{N} \times$ 
$\mathrm{P}$ interaction had significant influence on harvest index, highest harvest index was found with $\mathrm{N}$ and $\mathrm{P}$ applied at 25 and $60 \mathrm{~kg} \mathrm{P}_{2} \mathrm{O}_{5} /$ ha, respectively (Table 4).

The maximum gross return, net return, benefit: cost (B : C) ratio, PE and ME of mungbean were obtained when $\mathrm{N}$ was applied @ $40 \mathrm{~kg} / \mathrm{h}$. In case of $\mathrm{P}$ application the highest gross return, net return, $\mathrm{B}: \mathrm{C}$ ratio, $\mathrm{PE}$ and $\mathrm{ME}$ were observed at $60 \mathrm{~kg} \mathrm{P}_{2} \mathrm{O}_{5} /$ ha but it was statistically at par with $80 \mathrm{~kg} \mathrm{P}_{2} \mathrm{O}_{5} /$ ha (Table 5).

Among interaction effect of $\mathrm{N} \times \mathrm{P}$, the maximum net return, $\mathrm{B}: \mathrm{C}$ ratio, $\mathrm{PE}$ and $\mathrm{ME}$ were found in treatment combination of $40 \mathrm{~kg} \mathrm{~N} / \mathrm{ha}$ and $60 \mathrm{~kg} \mathrm{P}_{2} \mathrm{O}_{5} / \mathrm{ha}$ which was significantly greater than all other treatment combinations (Table 6). Ashraf et al. (2003) also reported that application of NP@50 - 50 kg/ha significantly increased the production and monetary efficiency of mungbean.

Table 6. Interaction effect of nitrogen and phosphorus on gross, net returns, B : C, K production efficiency and monetary efficiency of mungbean.

\begin{tabular}{|c|c|c|c|c|c|c|}
\hline \multirow{2}{*}{$\begin{array}{l}\mathrm{N} \& \mathrm{P} \\
\text { levels }\end{array}$} & \multicolumn{3}{|c|}{ Net returns (AFN/ha) } & \multicolumn{3}{|c|}{ B : C Ratio } \\
\hline & $\mathrm{N}_{1}$ & $\mathrm{~N}_{2}$ & $\mathrm{~N}_{3}$ & $\mathrm{~N}_{1}$ & $\mathrm{~N}_{2}$ & $\mathrm{~N}_{3}$ \\
\hline $\mathrm{P}_{1}$ & 84,698 & $1,21,794$ & 95,102 & 1.8 & 2.5 & 1.9 \\
\hline $\mathrm{P}_{2}$ & $1,10,578$ & $1,42,841$ & 94,948 & 2.3 & 2.9 & 1.9 \\
\hline $\mathrm{P}_{3}$ & $1,11,255$ & $1,21,318$ & 113,758 & 2.2 & 2.4 & 2.2 \\
\hline \multirow[t]{2}{*}{$\operatorname{LSD}(0.05)$} & \multicolumn{3}{|c|}{18473.9} & \multicolumn{3}{|c|}{0.38} \\
\hline & \multicolumn{3}{|c|}{$\begin{array}{l}\text { Production efficiency } \\
(\mathrm{kg} / \mathrm{ha} / \text { day })\end{array}$} & \multicolumn{3}{|c|}{$\begin{array}{c}\text { Monetary efficiency } \\
\text { (AFN/ha/day) }\end{array}$} \\
\hline $\mathrm{P}_{1}$ & 17.8 & 23.2 & 18.9 & 941 & 1353 & 1056 \\
\hline $\mathrm{P}_{2}$ & 21.8 & 25.9 & 19.3 & 1228 & 1587 & 1055 \\
\hline $\mathrm{P}_{3}$ & 21.9 & 22.9 & 22.6 & 1236 & 1348 & 1264 \\
\hline $\operatorname{LSD}(0.05)$ & \multicolumn{3}{|c|}{2.93} & \multicolumn{3}{|c|}{205.27} \\
\hline
\end{tabular}

The study re inferred that growth attributes of mungbean increased up to the nitrogen level of $55 \mathrm{~kg} \mathrm{~N} / \mathrm{ha}$ but yield attributes, yields, gross returns, net returns B : C ratio, production efficiency and monetary efficiency were highest when nitrogen was applied @ $40 \mathrm{~kg} \mathrm{~N} / \mathrm{ha}$. Likewise, growth parameters and biological yield increased with increasing $\mathrm{P}$ levels up to $80 \mathrm{~kg}$ $\mathrm{P}_{2} \mathrm{O}_{5} /$ ha, but the yield attributes, grain yield, gross returns, net returns, $\mathrm{B}: \mathrm{C}$ ratio, production efficiency and monetary efficiency were highest with $60 \mathrm{~kg} \mathrm{P}_{2} \mathrm{O}_{5} / \mathrm{ha}$ application. The best combination of nitrogen and phosphorus was found to be $40 \mathrm{~kg}$ $\mathrm{N} / \mathrm{ha}+60 \mathrm{P}_{2} \mathrm{O}_{5} / \mathrm{ha}$ in terms of yield and profitability.

\section{References}

Ashraf M, Muddin M and Naseer HW 2003. Production efficiency of mungbean (Vigna radiata L.) as affected by seed inoculation and NPK application. Italian J. Agric. Biol. 5(2): 179-180.

Dass A, Patnaik US and Sudhishri S 2005. Response of vegetable pea to sowing dates and phosphorus under on-farm conditions. Indian J. Agron. 50 (1): 64-66.

Dass A, Kharwara PC and Rana SS 1997. Response of gram varieties to sowing dates and phosphorus under on-farm conditions. Himachal J. Agric. Res. 23 (1\&2): 112-115. 
Gomez KA and Gomez AA 1984. Statistical procedures for agricultural research. New York: WileyInterscience. p. 680.

Karle AS and Pawar GG 1998. Effect of legume residue incorporation and fertilizer in mungbean-sunflower cropping system. J. Maharastha Agric. Univ. 23(3): 333-334.

Khan MB, Asif M, Hussain N and Aziz M 2003. Impact of different levels of phosphorus on growth and yield of mungbean genotype. Asian J. Plant Sci. 2(9): 677-679.

Mian MAK and Hossain J 2014. Nitrogen levels and physiological Basis of yield of Mungbean at varying plant population. Pakistan J. Bio. Sci. DOI: 10.3923.

Morton F, Smith RE and Pehlman JM 1982. Effect of nitrogen on growth and yield of mungbean. Department of Agronomy and Soils Mayaguez, Puerto Rico cp: 23.

Omran AH, Dass A, Jahish F, Dhar S, Choudhary AK and Rajanna GA 2018. Response of mungbean (Vigna radiata L.) to phosphorus and nitrogen application rates in Kandahar region of Afghanistan. Ann. Agric. Res. 39(1) in press.

Prasad NE and Kerketta R 1991. Soil fertility as influenced by different cropping sequences. Indian J. Agric. Sci. 61(1): 16-19.

Prasad SK, Singh MK and Jay S 2014. Response of rhizobium inoculation and phosphorus levels on mungbean (Vigna radiata) under guava-based agri-horti system. Save Nat. Sur. 9(2): 557-560.

Quah SC and Jaafar N 1994. Effect of nitrogen fertilizer on seed protein of mungbean. Applied biology beyond the year 2000: proceeding of the third symposium of Malaysian Society of Applied Biology. pp. 72-74.

Ullah A, Ali A, Waseem M, Nadeem MA, Tahir M, Iqbal A and Haseeb R 2010. Response of two mungbean cultivars with different phosphorus levels under Faisalabad condition. Int. J. App. Agric. Res. 5(5): 621628.

USAID 2007. Afghanistan Alternative Livelihoods Program-Eastern Region. International Center for Agriculture Research in the Dry Areas, Afghanistan Program (ICARDA). pp. 6-7.

Zabir A 2015. Effect of nitrogenous fertilizer on yield of mungbean (Vigna radiate L.) in Patuakhali district of Bangladesh. Asian J. Bio. Res. 1(3): 508-517. 